\title{
Preservation News
}

\section{Preserving e-journals}

D-Lib magazine's September 2001 issue (v.7: no.9) includes an article by Dale Flecker of Harvard University titled "Preserving Scholarly E-Journals." The article describes recent discussions among publishers, librarians, technologists, and others interested in preserving electronic resources that resulted in an Andrew W. Mellon Foundation grant initiative to explore the creation and operation of persistent e-journal archives. Mellon has awarded seven one-year planning grants to investigate four aspects of such archiving. The article also succinctly describes the issues involved in creating ejournal archives, e.g., the publisher/archive/subscriber relationship; how, when, and who can access archive content; comprehensiveness of content; normalized file formats; standard ingest formats; delivery of usable documents vs. bits; and sustainable financial models.

The article is available at http://www.dlib.org/ $\mathrm{dlib} /$ september01/flecker/09flecker.html.

\section{ANSI approves Dublin Core}

The American National Standards Institute (ANSI) has approved the Dublin Core Metadata Element Set as a new standard to be known as Z39.85-2001. The set defines 15 metadata elements that can be used as descriptors for Webbased documents to facilitate retrieval, use, and management. The elements are title, subject, description, source, language, relation, coverage, creator, publisher, contributor, rights, date, type, format, and identifier. This concise group of elements is the result of six years of consensus building among librarians, digital library researchers, content providers, and text-markup experts, led by the Dublin Core Metadata Initiative. A committee of the National Information Standards Organization (NISO) produced the standard presented to ANSI for approval. NISO is accredited by ANSI to develop technical standards related to information delivery.

The standard is available for free pdf download or purchase for $\$ 32$ at http://www. techstreet.com/cgi-bin/detail?product_id=926135.

\section{IMAP Web site}

Independent Media Arts Preservation (IMAP) is a consortium organized in 1999 to ensure preser- vation of independent electronic media for cultural and educational use. IMAP defines independent electronic media as "time-based, non-commercial production incorporating video or audio," e.g., video art, technology-based installation art, independent documentary and narratives, or community media. The IMAP Web site contains information about the preservation and cataloging of this type of media. They have developed a cataloging template based on standard MARC cataloging fields using a FileMaker Pro database (Windows or Macintosh). Although designed for use by those with no library cataloging experience, the template and a proposed union catalog may prove helpful to librarians.

For more information about IMAP and the cataloging template, consult their Web site at http://www.imappreserve.org.

\section{Building digital collections}

The Council on Library and Infomation Resources (CIIR) has published three reports examining the challenges involved in building coherent digital library collections that complement collections in other formats. The first, publication 99, is Selection and Presentation of Commercially Available Electronic Resounces: Issues and Practices by Timothy D. Jewell. The second, publication 100, is Building and Sustaining Digital Collections: Models for Libraries and Museums. The third, publication 101, is Strategies for Building Digitized Collections by Abby Smith. They cover, respectively, integration of commercial online publications into existing library collections, business models suitable for nonprofit organizations that can effectively sustain online collections, and "reselection" or the selection of collections for digital conversion.

All three reports are available for free at http://www.clir.org/pubs/reports/reports.html or for purchase from CLIR, 1755 Massachusetts Ave., N.W., Suite 500, Washington, D.C. 20036-2124; phone: (202) 939-4750; fax: (202) 939-4765; email: info@clir.org. The print copy of publication 99 costs $\$ 20,100$ costs $\$ 15$, and 101 costs $\$ 20$, plus shipping and handling.

Jane Hedberg is preservation program officer at Harvard University, e-mail: jane_hedberg@harvard.edu; fax: (617) 496-8344 


\section{The SPARC/ACRL Forum}

\section{ALA Midwinter Meeting 2002 New Orleans}

Saturday, January 19, 9:30-11:00 am

\section{Academic} Institutions

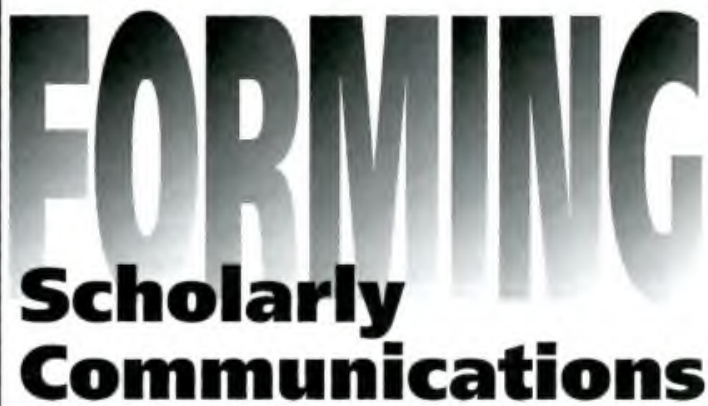

This session will illustrate for SPARC members and librarians interested in scholarly communication initiatives the variety of ways that academic institutions are transforming the scholarly communication process. In this very practical session, participants will:

- learn about MIT's Dspace project and how it might be tailored to their community

- discover the ways that metadata harvesting and open archiving software can be easily installed and used in a university setting

- discuss electronic publishing initiatives that have sprung up in academic environments

- interact with editors from the Journal of Machine Learning Research, the scholar-founded and -published journal produced in cooperation with MIT Press.

For more information: wruvv.arl.org/sparc
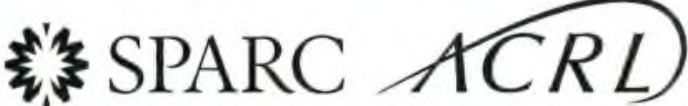

The SPARC/ACRL Forum is jointly sponsored by SPARC and the Association of College \& Research Libraries. 